\title{
DAMPAK PEMBANGUNAN PERUMAHAN TERHADAP PERUBAHAN SOSIAL MASYARAKAT DESA (STUDI DI DESA JAYAMEKAR, KABUPATEN BANDUNC BARAT)
}

\section{THE IMPACT OF HOUSING DEVELOPMENT ON THE SOCIAL CHANGE OF VILLAGERS (CASE OF JAYAMEKAR VILLAGE, BANDUNG BARAT DISTRICT)}

\author{
Dian Herdiana \\ Sekolah Tinggi Ilmu Administrasi (STIA) Cimahi; Jalan Raya Cibeber No. 148 Cimahi; kyberdian@gmail.com
}

Info Artikel:

- Artikel Masuk: 26/09/2018

\begin{abstract}
ABSTRAK
Perubahan sosial merupakan realitas yang tidak bisa dihindari oleh suatu masyarakat, termasuk masyarakat yang ada di perdesaan. Banyak faktor yang mempengaruhi perubahan sosial, salah satunya yaitu adanya pembangunan perumahan yang berada di lingkungan perdesaan yang secara langsung tidak hanya memungkinkan masyarakat luar untuk datang dan bertempat tinggal di desa tersebut, tetapi juga nilai-nilai dari luar yang dibawa masyarakat pendatang akan masuk dan berakulturasi dengan nilai-nilai lokal setempat yang berimplikasi merubah struktur sosial yang ada. Tujuan penelitian ini untuk mengkaji bagaimana dampak pembangunan perumahan terhadap perubahan sosial masyarakat yang ada di Desa Jayamekar Kabupaten Bandung Barat. Penelitian ini menggunakan pendekatan kualitatif, pengumpulan data melalui wawancara dan observasi. Teknik analisis data dilakukan melalui reduksi data, penyajian data, penafsiran data dan penarikan kesimpulan. Hasil penelitian menunjukan bahwa perubahan sosial yang ada di Desa Jayamekar Kabupaten Bandung Barat dikelompokan kepada 2 (dua) perubahan utama, yaitu: Pertama, perubahan pola pikir yang mana masyarakat desa menerima nilai-nilai baru yang berasal dari luar seperti cara berfikir logis dan orientasi berfikir kepada masa depan. Kedua, perubahan pola tindak yang mana masyarakat desa bersikap menerima kehadiran masyarakat pendatang dan melakukan interaksi sosial dalam berbagai bentuk aspek kehidupan. Perubahan sosial tersebut tidak hanya membawa dampak positif, tetapi juga membawa dampak negatif seperti turunnya nilai kepedulian sosial dan memunculkan sikap individualistis.
\end{abstract}

Kata Kunci : Pembangunan, Perumahan, Desa, Masyarakat, Perubahan Sosial.

\section{ABSTRACT}

Social change is an unavoided reality for the society, including for the villagers. Many factors influence the social change, one of them is the housing development in a village area which does not only allow outsiders to come and live in the village, but also allow external values brought by the outsiders to influx and acculturate with the local values. The purpose of this research is to analyze the impact of housing development on social change in Jayamekar Village, Bandung Barat District. This research uses qualitative approach, data collection through interview and observation. Data analysis technique through data reduction, data presentation, data interpretation and conclusion. The result of the research shows that the social change in Jayamekar Village, Bandung Barat District is grouped into 2 (two) main changes, namely: first, mindset changes in which villagers accept new values that come from outside such as logical thinking and the future orientation thinking. Second, behavior changes in which the villagers accept the presence of outsiders and making social interaction in various aspects of life. These social changes not only bring positive impacts but also bring negative impacts such as a decrease in social care and an increase in individualistic behavior.

Keyword: Development, Housing, Rural, Community, Social Change.

Copyright $\odot 2018$ JPWK-UNDIP This open access article is distributed under a Creative Commons Attribution (CC-BY-NC-SA) 4.0 International license.

Cara men-sitasi (APA 6th Style):

Herdiana, Dian. (2018). Dampak Pembangunan Perumahan Terhadap Perubahan Sosial Masyarakat Desa (Studi Di Desa Jayamekar, Kabupaten Bandung Barat). Jurnal Pembangunan Wilayah dan Kota, vol 14 (4), 265-280 


\section{PENDAHULUAN}

Kecamatan Padalarang Kabupaten Bandung Barat dilihat dari luas wilayah (BPS Kabupaten Bandung Barat, 2018) merupakan kecamatan terkecil (3\%) dibanding dengan luas Kabupaten Bandung Barat dan sekaligus menjadi kecamatan padat penduduk ( $\left.3.478 \mathrm{jiwa} / \mathrm{km}^{2}\right)$, meskipun begitu Kecamatan Padalarang merupakan salah satu kecamatan dengan tingkat pertumbuhan wilayah paling pesat dibanding dengan wilayah lainnya.

Pesatnya pertumbuhan ekonomi di Kecamatan Padalarang dikarenakan selain diorientasikan menjadi pusat ekonomi terpadu di Kabupaten Bandung Barat (Husodo, 2018) juga dikarenakan posisinya yang berbatasan dengan Kota Bandung dan Kota Cimahi sehingga secara geografis dijadikan daerah penyangga ekonomi/city's hinterland (Epstein, 1969) bagi kedua kota tersebut, hal ini sejalan dengan pemahaman Evans dalam (Vioya, 2010) bahwa kondisi perekonomian akan mampu mengidentifikasi perkembangan kawasan.

Konsekuensi dari pertumbuhan ekonomi yang pesat di Kecamatan Padalarang tersebut yaitu adanya kebutuhan akan perumahan untuk menunjang aktivitas ekonomi, kondisi perkembangan permukiman yang ada di pinggir kota (dalam hal ini pembangunan kompleks perumahan di desa-desa yang ada di Kecamatan Padalarang) sebagai implikasi dari adanya kebutuhan ruang di perkotaan (Giyarsih, 2001) yang secara langsung memperbesar kemampuan perkotaan (dalam hal ini Kota Bandung dan Kota Cimahi) untuk menyediakan beragam jenis perumahan yang terus meningkat (Diningrat, 2014).

Kompleks perumahan tersebut dibangun di 10 (sepuluh) desa yang ada di Kecamatan Padalarang. Perumahan yang telah dibangun tidak hanya diperuntukan bagi kalangan masyarakat menengah/bawah, tetapi juga diperuntukan bagi kalangan masyarakat menengah/atas. Bahkan beberapa perumahan yang sudah dibangun menawarkan konsep kota mandiri (Batudoka, 2005) dimana pihak pengembang (developer) menjamin ketersediaan sarana dan prasarana kebutuhan dasar lingkungan permukiman (Kalsum, Caesariadi, \& Wibowo, 2016) seperti sarana ibadah, sarana pendidikan sampai dengan sarana kesehatan.

Pembangunan perumahan yang diartikan sebagai penggunaan dan/atau pengembangan tanah kosong untuk tempat tinggal (Harjanto \& Hidayati, 2003) tidak hanya berdampak kepada berkurangnya lahan untuk pertanian di desa-desa yang ada di Kecamatan Padalarang, tetapi juga terhadap kehidupan masyarakat desa. Adanya perubahan alih fungsi lahan menjadi perumahan selama lebih dari satu dekade tersebut telah merubah mata pencaharian masyarakat (Dewi \& Sarjana, 2015) yang awalnya sebagai petani bergeser kepada mata pencaharian lainnya seperti di bidang perdagangan, bidang perindustrian dan bidang jasa. Sedangkan masyarakat yang masih bekerja di bidang pertanian sebanyak 9.092 jiwa (5.1\%) dari total keseluruhan penduduk di Kecamatan Padalarang sebanyak 178.743 jiwa (BPS Kabupaten Bandung Barat, 2018).

Selain terjadinya peralihan mata pencaharian masyarakat desa, dengan adanya masyarakat pendatang/internal migration (Purnomo, 2009) yang menghuni kompleks perumahan secara langsung memberi dampak terhadap perubahan sosial masyarakat desa yang selama ini ada. Terjadinya interaksi nilai-nilai yang berbeda sebagai bentuk dari adanya komunikasi warga masyarakat dengan latar belakang yang berbeda/interculture communication (Fiske, 2011), sehingga dalam prosesnya akan merestrukturisasi tatanan nilai dan struktur masyarakat yang ada yang muncul sebagai penyesuaian antara kedua nilai tersebut.

Masyarakat pendatang memiliki nilai-nilai yang berbeda dengan nilai-nilai yang ada di masyarakat desa selama ini, ketika masyarakat pendatang penghuni kompleks perumahan diasosiasikan dengan masyarakat perkotaan dengan tatanan nilai heterogen (Rusdiyanta \& Syarbaini, 2009) dan relasi sosial yang rendah, sebaliknya masyarakat desa memiliki tatanan nilai yang homogen dan relasi sosial yang tinggi. Perbedaan karakter masyarakat desa dengan masyarakat pendatang ini pada akhirya akan berpengaruh terhadap relasi dan interaksi sosial yang ada di Desa Jayamekar, perbedaan karakter lainnya dapat dijelaskan dalam Tabel 1. berikut ini. 
Tabel 1. Perbedaan Karakter Desa dan Karakter Kota. (Luthfia, 2013)

\begin{tabular}{|ll|}
\hline \multicolumn{1}{|c|}{ Karakter Desa } \\
$\begin{array}{l}\text { Faktor geografik yang menentukan dasar pembentukan } \\
\text { kelompok. }\end{array}$ & Anonimitas merupakan ciri kehidupan masyarakatnya. \\
\hline Hubungan lebih bersifat intim dan awet. & Mobilitas sosial tinggi. \\
\hline Mobilitas rendah. & Tergantung pada spesialisasi. \\
\hline
\end{tabular}

Dari tabel tersebut di atas didapat informasi bahwa sesungguhnya karakter yang berbeda ditunjukan antara desa dan kota yang dalam hal ini direpresentasikan dengan masyarakat desa dan masyarakat pendatang. Dikaitkan dengan pembangunan perumahan, konsep perumahan dalam realitas sosial tidak hanya diartikan sebagai bangunan fisik semata, tetapi juga di dalamnya sebagai tempat individu-individu berinteraksi dan saling mempengaruhi (Abrams, 1964), sehingga dalam proses interaksi sosial antara masyarakat desa dengan masyarakat pendatang, maka akan terjadi transfer nilai dan budaya diantara keduanya yang berimplikasi kepada enkulturasi budaya (Alo, 1991) antara budaya masyarakat desa dengan budaya yang dibawa masyarakat pendatang. Hal tersebut akan merubah nilai-nilai yang ada di masyarakat desa baik secara individu seperti pandangan hidup dan perubahan perilaku, maupun secara sosial berupa perubahan tatanan sosial masyarakat. Sehingga pada akhirnya terjadi asimilasi yang melahirkan kesamaan faham budayawi (Ritonga \& Bahri, 2017) dan membentuk nilai baru sebagai fondasi relasi hubungan masyarakat desa dengan masyarakat pendatang.

Atas dasar permasalahan tersebut di atas, maka penelitian ini dimaksudkan untuk mengkaji dampak sosial dari pembangunan perumahan terhadap perubahan sosial masyarakat desa. Adapun yang menjadi lokus penelitian adalah Desa Jayamekar Kabupaten Bandung Barat, alasan pemilihan Desa Jayamekar sebagai lokus penelitian yaitu; Pertama, sudah didirikan 14 (empat belas) perumahan yang ada di Desa Jayamekar. Kedua, tingkat mobilitas masyarakat yang tinggi dengan rata-rata penduduk datang dan pindah sebanyak 406 per tahun (Pemerintah Desa Jayamekar, 2018). Ketiga, Desa Jayamekar termasuk 3 besar desa di Kecamatan Padalarang dengan heteogenitas tertinggi seperti contohnya mata pencaharian dan agama (Pemerintah Desa Jayamekar, 2018). Secara teoritis, penelitian ini diharapkan mampu memperkaya pemahaman konseptual mengenai dampak perubahan sosial dilihat dalam perspektif masyarakat desa. Secara praktis penelitian ini diharapkan mampu memberikan gambaran bagi stakeholders yang ada di Kecamatan Padalarang dalam merekontruksi kebijakan pembangunan kawasan perumahan di lingkungan perdesaan dikaitkan dengan aspek perubahan sosial.

\section{DATA DAN METODE}

\subsection{GAMBARAN UMUM DESA JAYAMEKAR KABUPATEN BANDUNG BARAT}

Desa Jayamekar merupakan desa yang terletak di Kecamatan Padalarang, Kabupaten Bandung Barat, Jawa Barat. Desa Jayamekar merupakan desa hasil pemekaran dari Desa Cibugel pada tahun 1982 pada waktu Kecamatan Cibugel masih sebagai Kamantren, luas wilayah Desa Jayamekar yaitu 5,77 km² dengan jumlah penduduk sebanyak 18.582 jiwa (Pemerintah Desa Jayamekar, 2018). Batas wilayah Desa Jayamekar dengan desa lainnya dapat dijelaskan dalam Tabel 2. berikut ini:

Tabel 2. Batas Wilayah Desa Jayamekar (Pemerintah Desa Jayamekar, 2018)

\begin{tabular}{|lll|}
\hline \multicolumn{1}{|c|}{ Batas } & \multicolumn{1}{c|}{ Desa } & \multicolumn{1}{c|}{ Kecamatan } \\
\hline Sebelah Utara & Padalarang & Padalarang \\
\hline Sebelah Selatan & Kertajaya, Bojong Haleuang & Padalarang, Batujajar \\
\hline Sebelah Timur & Kertajaya, Padalarang & Padalarang \\
\hline Sebelah Barat & Gunung Masigit & Cipatat \\
\hline
\end{tabular}


Untuk lebih jelasnya, batas wilayah Desa Jayamekar dengan desa lainnya dapat dilihat dalam Gambar 1. berikut ini:

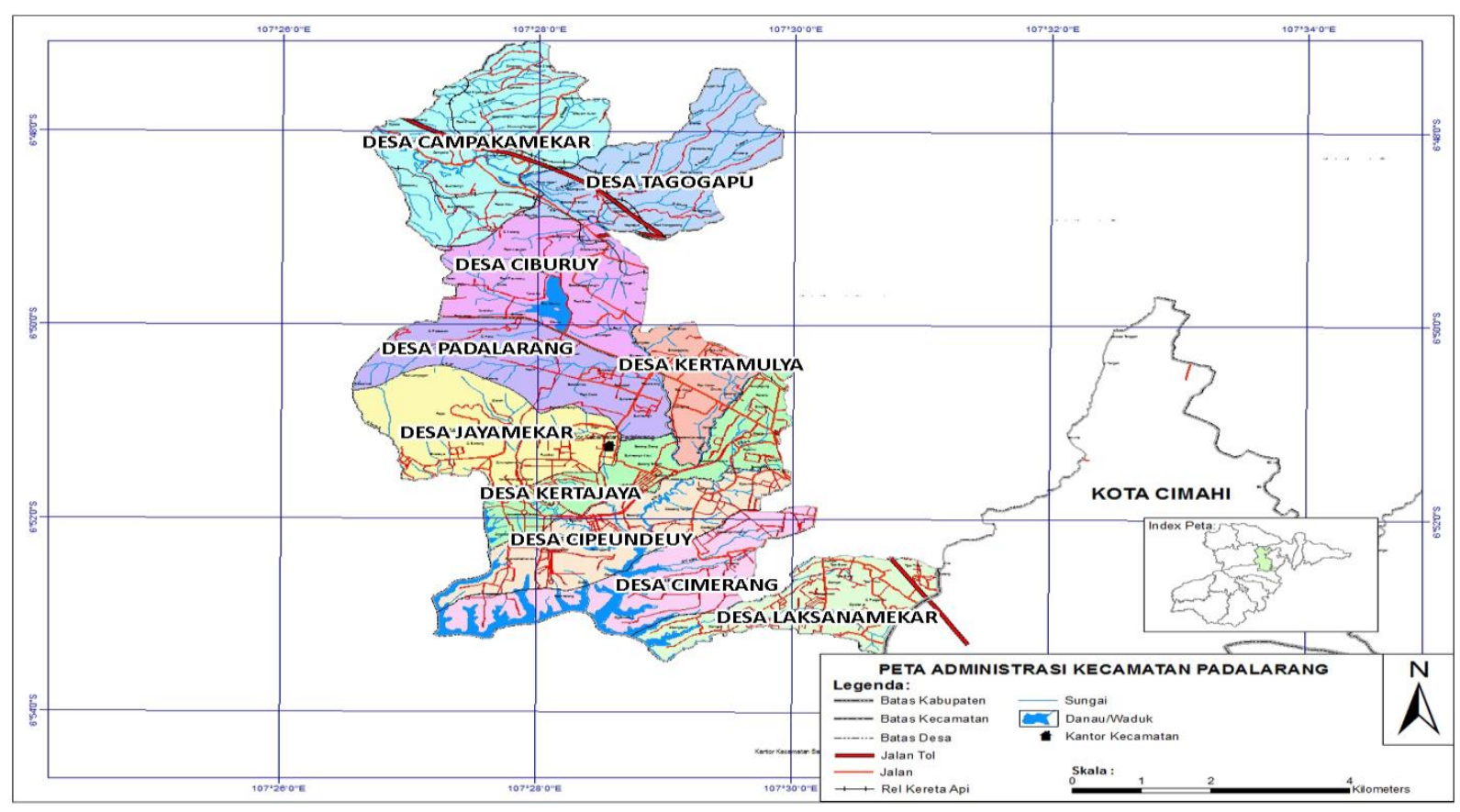

Gambar 1. Peta Administratif/Batas Wilayah Desa Jayamekar (Pemerintah Desa Jayamekar, 2018)

Dilihat dari aspek tipologi desa yang ada di Indonesia (Sari, Safitri, \& Sugito, 2014) Desa Jayamekar dapat dikategorikan sebagai desa perkotaan, hal ini setidaknya didasarkan kepada 3 ciri utama baik fisik maupun non-fisik yaitu: Pertama, dilihat dari aspek infrastruktur, Desa Jayamekar sudah memiliki sarana prasarana penunjang kegiatan masyarakat baik ekonomi maupun kesehatan, seperti bisa dilihat dalam Tabel 3. berikut ini:

Tabel 3. Sarana Ekonomi dan Kesehatan Desa Jayamekar (Pemerintah Desa Jayamekar, 2018)

\begin{tabular}{|ll|}
\multicolumn{1}{c}{ Sarana/Prasarana } & \multicolumn{1}{c|}{ Jumlah } \\
\hline Jalan Desa & Kondisi sudah di aspal dan/atau di beton, akses ke gerbang tol padalarang: \pm 15 menit. \\
\hline Pasar & Pasar Non-Permanen: 30, Toko: 120, Kios: 80. \\
\hline Sarana Kesehatan & Puskesmas: 1, Posyandu: 24, Apotek: 1, Tempat Praktek Bidan: 6. \\
\hline
\end{tabular}

Kedua, heterogenitas masyarakat desa dalam banyak aspek kehidupan seperti contohnya heterogenitas mata pencaharian yang bisa dilihat dalam Tabel 4. berikut ini:

Tabel 4. Jenis Mata Pencaharian Masyarakat (Pemerintah Desa Jayamekar, 2018)

\begin{tabular}{|cccccccccc|}
$\begin{array}{c}\text { Jenis } \\
\text { Pekerjaan }\end{array}$ & Pertanian & Perindustrian & Pertambangan & Perdagangan & Angkutan & PNS/Jasa & TNI/Polri & Lainnya \\
\hline Jumlah/jiwa & 1047 & 1379 & 78 & 1343 & 329 & 1192 & 108 & $\begin{array}{c}\text { Tidak } \\
\text { terdata }\end{array}$ \\
\hline
\end{tabular}

Ketiga, tingginya mobilitas penduduk yang datang (moving in) ke Desa Jayamekar maupun masyarakat Desa Jayamekar yang keluar desa (moving out) dalam setiap tahunnya yang bisa dilihat dalam Tabel 5. berikut ini: 
Tabel 5. Mobilitias Penduduk Desa Jayamekar. (BPS Kabupaten Bandung Barat, 2018)

\begin{tabular}{|cccccc|}
\hline \multicolumn{2}{|c}{ Jumlah Warga Datang (Moving in) } & \multicolumn{3}{c|}{ Jumlah Warga Pindah (Moving out) } \\
\hline Laki-Laki & Perempuan & Jumlah & Laki-Laki & Perempuan & Jumlah \\
\hline 180 & 179 & 359 & 195 & 209 & 404 \\
\hline
\end{tabular}

Ketiga alasan tersebut di atas yang menjadikan Desa Jayamekar berbeda dengan desa tradisional (Suparman, 2016) yang ada di Indonesia, yang mana desa tradisional masih dicirikan dengan homogenitas masyarakatnya dan rendahnya mobilitas dari dan ke desa.

Dilihat dari aspek kepadatan penduduk, dari total penduduk Desa Jayamekar yang berjumlah 18.582 jiwa dan menempati luas wilayah sebesar $5,77 \mathrm{~km}^{2}$ dapat dikatakan bahwa Desa Jayamekar merupakan desa dengan kepadatan penduduk yang cukup padat jika dibanding dengan desa lainnya yang ada di Kecamatan Padalarang yaitu sebesar 3,219 orang/ km² (BPS Kabupaten Bandung Barat, 2018). Kepadatan penduduk tersebut salah satunya disebabkan oleh pesatnya pertumbuhan ekonomi kawasan yang ada di Kecamatan Padalarang yang pada akhirnya menuntut kebutuhan perumahan/hunian untuk menunjang aktivitas pembangunan ekonomi tersebut.

Kompleksitas permasalahan tersebut, salah satunya berdampak kepada tuntutan akan pembangunan perumahan untuk menampung warga masyarakat baik sebagai dampak pertumbuhan penduduk masyarakat desa, maupun sebagai dampak banyaknya masyarakat pendatang. Pembangunan perumahan tersebut selain berimplikasi kepada tingginnya angka datang dan pergi penduduk desa yang tercatat sebanyak 359 jiwa penduduk datang dan bertempat tinggal di Desa Jayamekar (Pemerintah Desa Jayamekar, 2018), juga berakibat kepada heteroginitas masyarakat. Masyarakat yang dahulunya berasal dari satu suku yaitu suku sunda, kini telah ada masyarakat dari suku lainnya, begitu juga dengan aspek lainnya seperti mata pencaharian, tingkat pendidikan dan agama. Perkembangan desa dengan heteroginitas masyarakatnya membawa implikasi kepada perubahan sosial di Desa Jayamekar, interaksi masyarakat desa dengan masyarakat pendatang pada akhirnya membentuk tatanan kehidupan sosial baru yang diterima dan diterapkan oleh masyarakat sebagai nilai dan norma sosial bersama.

\subsection{METODE PENELITIAN}

Penelitian ini merupakan penelitian kualitatif dengan pendekatan deskriptif interpretatif (DeVault, Denzin, \& Lincoln, 1995) yang mana penggunaan metode ini bertujuan untuk mendeskripsikan dan menjelaskan tentang aspek-aspek perubahan sosial yang muncul sebagai dampak dari pembangunan perumahan di lingkungan perdesaan. Lebih lanjut penelitian kualitatif sering disebut sebagai metode penelitian naturalistik dengan instrumennya adalah orang/ human instrument (Sugiyono, 2013). Sehingga dalam penelitian ini peneliti berperan untuk mengumpulkan dan menginterpretasikan data yang diperoleh dari lapangan.

Penelitian deskriptif dapat diartikan sebagai sebuah prosedur penelitian yang berusaha mencari jalan pemecahan masalah yang diselidiki dengan menggambarkan/ melukiskan keadaan subjek/objek penelitian (seseorang, lembaga, masyarakat dan lain-lain) pada saat sekarang berdasarkan fakta-fakta yang tampak (Nawawi, 2007). Sehingga dalam penelitian ini fakta mengenai bagaimana perubahan sosial merupakan gambaran mengenai bagaimana sesungguhnya proses dan dampak perubahan sosial yang terjadi di Desa Jayamekar yang didasarkan kepada hasil penggalian data dari berbagai informan baik yang berasal dari aparatur pemerintah (baik aparatur yang ada di kantor Kecamatan Padalarang maupun aparatur yang ada di Kantor Pemerintah Desa Jayamekar), serta perwakilan masyarakat baik masyarakat asli yang lahir dan menetap di Desa Jayamekar maupun masyarakat pendatang yang berasal dari luar desa dan telah menetap di Desa Jayamekar.

Data dalam penelitian ini dibagi ke dalam dua jenis data, yaitu data primer dan data sekunder. Data primer diperoleh secara langsung di lapangan melalui wawancara dan observasi sedangkan data sekunder diperoleh dengan cara studi kepustakaan baik terhadap buku, jurnal, dokumen-dokumen maupun peraturan perundang-undangan yang berlaku. Proses analisis dalam penelitian ini dilakukan semenjak 
pengumpulan data yaitu dilakukan mulai dari awal penelitian dan selama proses penelitian. Teknik analisis data dilakukan melalui pengumpulan data, reduksi data, penyajian data dan penarikan kesimpulan (Moleong, 2017).

\section{HASIL DAN PEMBAHASAN}

\subsection{Perubahan Sosial di Desa Jayamakar}

Perubahan sosial dalam prakteknya tidak hanya dipengaruhi oleh satu faktor tunggal saja, melainkan oleh berbagai faktor yang mana faktor-faktor tersebut saling terkait antara satu dengan yang lainnya. Berdasarkan hasil penelitian yang dilakukan di Desa Jayamekar, faktor yang mempengaruhi perubahan sosial dapat dijelaskan dalam gambar 1 berikut ini:

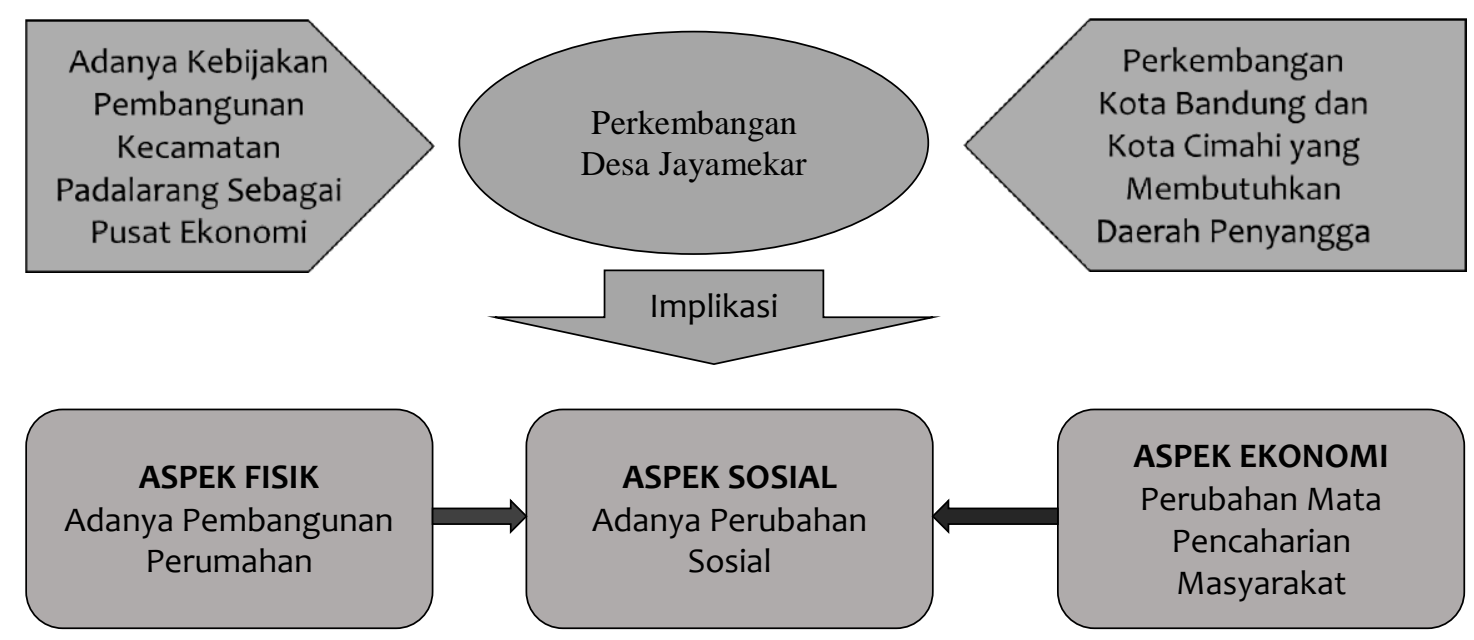

Gambar 1. Alur Perubahan Sosial (Analisis Peneliti, 2018)

Dari gambar tersebut, setidaknya terdapat dua faktor yang menyebabkan perubahan sosial. Pertama, adanya kebijakan pemerintah Kabupaten Bandung Barat yang menjadikan Kecamatan Padalarang sebagai salah satu pusat perekonomian. Kedua, adanya kebutuhan akan ruang penyangga bagi Kota Bandung dan Kota Cimahi, kedua faktor tersebut dapat dikategorikan sebagai faktor ekternal (external factor). Sedangkan faktor lainnya merupakan faktor internal yang berasal dari dalam (internal factor) yang mendorong perubahan di Desa Jayamekar sebagaimana dapat dijelaskan dalam tabel 6 berikut ini:

Tabel 6. Faktor Pendorong (Internal) di Desa Jayamekar (Analisis Peneliti, 2018)

\begin{tabular}{|c|c|}
\hline Aspek & Faktor Pendorong \\
\hline $\begin{array}{l}\text { Sarana dan } \\
\text { Prasarana Dasar. }\end{array}$ & $\begin{array}{l}\text { - Aksestabilitas yang mudah, dicapai dalam waktu } \pm 15 \text { menit dari pintu gerbang tol } \\
\text { padalarang. } \\
\text { - Ketersediaan jaringan listrik, jaringan telekominikasi, jaringan internet yang sudah } \\
\text { terbangun dengan baik. } \\
\text { - Ketersediaan sarana air bersih dan sistem sanitasi yang sudah baik. } \\
\text { - Ketersediaan transportasi umum ke desa maupun dari desa ke luar desa. }\end{array}$ \\
\hline $\begin{array}{l}\text { Sarana } \\
\text { Prasarana } \\
\text { Penunjang. }\end{array}$ & $\begin{array}{l}\text { - Tersedianya layanan pendidikan mulai dari pendidikan dasar sampai pendidikan lanjutan. } \\
\text { - Tersedianya layanan kesehatan bagi masyarakat baik itu Puskesmas maupun Klinik } \\
\text { Kesehatan. } \\
\text { - Tersedianya sarana olah raga bagi masyarakat seperti Gelanggang Olah Raga (GOR). } \\
\text { - Tersedianya sarana sosial seperti balai pertemuan desa dan sarana atau tempat ibadah. }\end{array}$ \\
\hline $\begin{array}{l}\text { Sarana dan } \\
\text { Prasarana Ekonomi. }\end{array}$ & $\begin{array}{l}\text { - Banyaknya pasar dan pertokoan (Pasar non-permanen: 30, toko: 120, Kios: 80). (BPS } \\
\text { Kabupaten Bandung Barat, 2018). }\end{array}$ \\
\hline
\end{tabular}




\begin{tabular}{|c|c|}
\hline Aspek & Faktor Pendorong \\
\hline & $\begin{array}{l}\text { - Adanya pengembangan Usaha Mikro Kecil Menengah (UMKM) seperti pembuatan cobek } \\
\text { dan alat rumah tangga dari batu alam. } \\
\text { - Dekat dengan layanan perbankan. } \\
\text { - Dekat dengan hotel dan restoran. }\end{array}$ \\
\hline
\end{tabular}

Dari adanya faktor pendorong (internal) yang ada tersebut di atas, maka secara otomatis memunculkan keterkaitan antara Desa Jayamekar sebagai daerah penyangga dengan kota utama yaitu Kota Bandung dan Kota Cimahi baik dalam aspek fisik/infrastruktur maupun dalam aspek ekonomi yang dapat dijelaskan dalam tabel 7 sebagai berikut ini:

Tabel 7. Keterkaitan Desa Jayamekar dan Kota Bandung/Kota Cimahi (Analisis Peneliti, 2018)

\begin{tabular}{|c|c|c|}
\hline & & \\
\hline $\begin{array}{l}\text { - Pengembangan permukiman atau perumahan. } \\
\text { - Pengembangan pembangunan sarana dan } \\
\text { prasarana penunjang seperti pendidikan, } \\
\text { kesehatan, dan lain-lain. }\end{array}$ & & $\begin{array}{l}\text { - Penyerap kebutuhan pemukiman atau } \\
\text { perumahan. } \\
\text { - Penyerap kebutuhan sarana dan prasarana } \\
\text { penunjang seperti pendidikan, kesehatan, } \\
\text { dan lain-lain. }\end{array}$ \\
\hline $\begin{array}{l}\text { - Penghasil produksi pertanian dan perkebunan. } \\
\text { - Pengembangan kawasan indrustri kecil dan } \\
\text { menengah. } \\
\text { - Pengembangan perdagangan sekunder. } \\
\text { - Penyedia Sumber Daya Manusia (SDM). }\end{array}$ & & $\begin{array}{l}\text { - Lokasi pemasaran hasil pertanian dan } \\
\text { perkebunan. } \\
\text { - Penyerap hasil produksi indrustri kecil dan } \\
\text { menengah. } \\
\text { - Pusat perdagangan primer. } \\
\text { - Penyerap Sumber Daya Manusia (SDM). }\end{array}$ \\
\hline
\end{tabular}

\subsection{Struktur Sosial Masyarakat Desa dan Masyarakat Pendatang}

Desa Jayamekar meskipun telah bertransformasi dari yang dahulunya merupakan desa tradisional dan menjadi desa perkotaan dengan segala perkembangan ekonomi dan infrastrukturnya, namun dalam hal struktur sosial masyarakat, khususnya struktur masyarakat desa yang sudah lama tinggal dan menetap tidak banyak berubah, perubahan struktur sosial yang ada lebih banyak diakibatkan karena adanya interaksi masyarakat desa dan masyarakat pendatang yang menghuni kompleks perumahan dimana kedua masyarakat tersebut memiliki nilai-nilai dan kebudayaan yang berbeda. Pada akhirnya pertemuan kedua nilai dan budaya tersebut menghasilkan nilai-nilai dan budaya yang baru yang membentuk perubahan sosial di Desa Jayamekar.

Dilihat dari aspek sosial, Desa Jayamekar sebagaimana desa lainnya di Jawa Barat memiliki karakter sosial yang menerapkan nilai-nilai budaya sunda, kepala desa yang dalam hal ini sering disebut Bapak "Kuwu" (Harmono, 2015) memegang peran yang penting tidak hanya sebagai pemimpin formal dalam penyelenggaraan pemerintahan desa, tetapi juga sebagai pemimpin sosial dalam tatanan kehidupan masyarakat desa. Hal ini berimplikasi kepada posisi kepala desa yang harus mampu mengayomi (Potabuga, 2015) masyarakat dalam setiap aspek kehidupan, keberadaan "Kuwu" tersebut diposisikan oleh masyarakat desa sebagai tokoh yang disegani dan dihormati.

Nilai-nilai sunda seperti harus saling menghormati dan saling menghargai (silih asih) dan harus saling mendorong serta membantu dalam kebaikan kehidupan bersama (silih asuh) (Masruri \& Lukman, 2013) menjadi nilai yang diadopsi dan dipraktekan dalam kehidupan masyarakat yang ada di Desa Jayamekar, sehingga pola hubungan interaksi yang dijalin oleh masyarakat desa dengan masyarakat luar salah satunya didasarkan kepada nilai-nilai tersebut.

Struktur sosial masyarakat terbentuk karena adanya ikatan kekeluargaan yang terjalin sejak lama, struktur sosial yang berdasar kepada kekeluargaan tersebut tidak hanya membentuk pola komunikasi antar warga masyarakat desa, tetapi juga membentuk pola hunian masyarakat yang mana anggota keluarga dari garis keturunan yang sama bertempat tinggal di Rukun Warga (RW)/Dusun yang sama, hal ini 
pada akhirnya membentuk relasi sosial antara sesama masyarakat secara baik dan intim. Dikarenakan struktur sosial yang terbentuk didasarkan kepada ikatan sosial, sehingga sifat solidaritas sosial, gotong royong dan musyawarah mufakat menjadi ciri dari masyarakat Desa Jayamekar.

Berbeda dengan masyarakat yang sudah lama tinggal di Desa Jayamekar, masyarakat pendatang yang menghuni perumahan pada dasarnya memiliki struktur sosial yang terbuka dan bersifat pragmatis, jalinan sosial didasarkan kepada kepentingan dengan pihak/warga masyarakat lainnya, sehingga relasi sosial yang terjalin tidak bersifat intim/erat. Akibat dari hal tersebut, masyarakat pendatang pada umumnya memiliki solidaritas sosial dan sifat gotong royong yang rendah, hal ini dikarenakan struktur sosial yang dibangun secara praktis berdasarkan kepentingan, yang mana hal ini memiliki keterbatasan yaitu relasi tersebut akan terjalin sepanjang ada kepentingan dan akan hilang ketika kepentingan tersebut sudah tecapai.

Aspek yang lain yang membedakan masyarakat yang sudah lama tinggal di Desa Jayamekar dengan masyarakat pendatang yang menghuni kompleks perumahan adalah bentuk penghormatan kepada pemimpin formal dan pemimpin non-formal. Masyarakat asli yang bertempat tinggal di Desa Jayamekar menghormati dan menjalankan struktur sosial yang ada dimana struktur sosial terdiri dari dua poros utama yaitu "kuwu" dan "sesepuh". "Kuwu" merupakan sebutan lain bagi kepala desa yang mana masyarakat menghormati "kuwu" dikarenakan adanya kewenangan formal dalam penyelenggaraan pemerintahan. Sedangkan "sesepuh" merupakan tokoh yang dituakan atau dihormati oleh masyarakat dikarenakan peranan dan kontribusinya bagi masyarakat desa.

Posisi masyarakat pendatang dibagi kepada dua kelompok. Pertama, masyarakat pendatang yang memiliki sikap menghormati dan menghargai "kuwu" dan "sesepuh" sebagai struktur sosial yang ada di Desa Jayamekar, masyarakat pendatang ini biasanya berasal dari masyarakat desa lainnya yang mana di desa sebelumnya memiliki struktur sosial yang sama. Kedua, masyarakat pendatang yang memiliki sikap "formal-legal" artinya masyarakat hanya menghormati dan menghargai didasarkan kepada kepemilikan kewenangan dalam hal ini "kuwu", bukan "sesepuh", masyarakat pendatang ini berasal dari masyarakat perkotaan yang mana di tempat tinggal sebelumnya tidak mengenal struktur sosial desa.

\subsection{BENTUK INTERAKSI SOSIAL MASYARAKAT DESA DENGAN MASYARAKAT PENDATANG}

Interaksi sosial sebagai hubungan orang perorang, orang dengan kelompok maupun sesama kelompok (Walgito, 2010) merupakan kebutuhan yang tidak mungkin dihindari, interaksi sosial merupakan kunci dari kehidupan sosial karena tanpa adanya interaksi sosial, tidak mungkin ada kehidupan bersama (Soekanto, 1994). Dalam prakteknya interaksi sosial tersebut bisa berdampak kepada hal-hal yang baik (asosiatif) atau berdampak kepada hal-hal yang buruk (disasosiatif). Berikut adalah interaksi yang ada di Desa Jayamekar:

\subsubsection{Bentuk Interaksi Sosial Asosiatif di Desa Jayamekar}

\subsubsection{Kerjasama}

Masyarakat desa dan masyarakat pendatang melakukan interaksinya dan kerjasama, hal ini didasakan karena adanya kepentingan yang sama (Soekanto, 1994) yaitu untuk bisa hidup berdampingan di wilayah Desa Jayamekar. Berikut adalah bentuk kerjasama yang dijalin antara masyarakat desa dengan masyarakat pendatang:

\section{A. Gotong Royong}

Gotong-royong antara masyarakat desa dengan masyarakat pendatang terjalin dalam berbagai bentuk sebagaimana dapat dijelaskan berikut ini:

- Pertama, gotong royong dalam pembangunan desa dimana kedua warga masyarakat tersebut turut serta dalam pembangunan desa mulai dari tahap perencanaan sampai tahap pelaksanaan. Pada tahap perencanaan pembangunan desa, kedua kelompok masyarakat selain sama-sama berpartisipasi dalam perencanaan pembangunan yaitu Musyawarah Desa (MusDes) dan Musyawarah Perencanaan Pembangunan Desa (Musrembang Desa). Dalam tahap pelaksanaan pembangunan desa kedua 
kelompok masyarakat sama-sama berpartisipasi dalam berbagai program pembangunan desa seperti perbaikan jalan, perbaikan irigasi dan lain-lain.

- Kedua, gotong royong dalam menjaga keamanan dan ketentraman lingkungan, baik masyarakat desa maupun masyarakat pendatang memiliki kebutuhan yang sama yaitu rasa aman dan tentram. Hal ini diwujudkan oleh kedua kelompok warga dengan membangun sikap toleransi dengan tidak mengadakan kegiatan yang dapat mengganggu keamanan dan kententraman seperti pesta narkoba dan mabukmabukan.

Perbedaan dalam aspek keamanan antara masyarakat desa dengan masyarakat pendatang yang menghuni kompleks perumahan yaitu untuk lingkungan desa masyarakat mengadakan sistem keamanan lingkungan (Siskamling) sedangkan pengamanan di kompeks perumahan dilakukan oleh satpam atau satuan pengamanan khusus (security), namun dalam prakteknya sikap anggota satuan pengamanan kompleks perumahan (Satpam) selain menjaga kompleks perumahannya masing-masing juga bekerjasama dengan pihak pemerintah desa (Siskamling) apabila ditemukan gangguan keamanan atau pelanggaran hukum.

- Ketiga, bentuk kerja sama lainnya antara masyarakat desa dengan masyarakat pendatang yaitu seperti bergabung di organisasi desa seperti karang taruna, menjadi anggota Pembinaan Kesejahteraan Keluarga (PKK) dan organisasi desa lainnya, terdapat juga bentuk kerjasama yang dilakukan oleh masyarakat desa dengan masyarakat pendatang di bidang ekonomi seperti pembukaan jenis usaha bersama.

\section{B. Bergaining}

Hubungan bergaining antara masyarakat desa dengan masyarakat pendatang bisa dilihat dalam pengelolaan saluran pembuangan dan sampah rumah tangga, masyarakat pendatang tidak boleh membuang sampah rumah tangga di sembarang tempat, terlebih lagi menyalurkan limbah cair rumah tangga yang dapat mengganggu masyarakat desa, khususnya mengganggu ladang dan pertanian. Proses bergaining ini pada akhirnya dilakukan oleh pihak pengembang (developer) dan pemerintah desa dimana masyarakat pendatang penghuni kompleks perumahan mengikuti kebijakan yang telah menjadi kesepakatan bersama. Bergaining yang ada di Desa Jayamekar selama ini berlangsung dengan baik dan menguntukngkan kepada kedua belah pihak, tidak ditemukan proses bergaining yang mana satu pihak merugikan atau mendominasi kepentingan pihak lainnya.

\subsubsection{Akomodasi}

\section{A. Kompromi}

Bentuk kompromi yang dilakukan masyarakat desa dengan masyarakat pendatang terjalin dalam banyak hal, seperti:

- Masalah nilai-nilai moral, kedua kelompok masyarakat sepakat untuk mencegah berbagai kegiatan yang bertentangan dengan nilai-nilai moral/agama seperti tindakan asusila atau praktek seks bebas, minuman beralkohol dan kegiatan buruk lainnya meskipun kedua kelompok masyarakat menganut keyakinan/agama yang berbeda-beda.

- Masalah infrastruktur desa, kedua kelompok masyarakat sepakat meskipun kompleks perumahan tertutup namun bukan berarti masyarakat desa tidak bisa mengakses ke dalam kompleks perumahan. Pembangunan infrastruktur yang menjadi fasilitas umum bisa dipergunakan oleh kedua kelompok masyarakat.

- Perbedaan-perbedaan lainnya yang masih bisa dibicarakan dan diselesaikan dengan cara musyawarah dan tanpa mengutamakan kepentingan atau ego pribadi dari masing-masing kelompok masyarakat.

\section{B. Toleransi}

Baik masyarakat desa maupun masyarakat pendatang sama-sama menjunjung tinggi nilai-nilai toleransi, hal ini mengingat keragaman keyakinan/agama yang dianut. Meskipun mayoritas penduduk desa 
memeluk agama Islam yaitu sebesar 17.824 warga, namun penganut agama lain juga tidak bisa dikatakan sedikit. Tercatat sebanyak 270 warga beragama kristen, 488 warga beragama protestan (BPS Kabupaten Bandung Barat, 2018). Keberagaman agama yang dianut disikapi dengan bijak oleh warga masyarakat desa yang beragama Islam dengan memberi ketentraman dan kebebasan untuk beribadah sesuai dengan agamanya masing-masing dan tidak mengusik apabila sedang mempraktekan ritual agamanya. Begitu pula dengan warga masyarakat yang beragama non-Islam menghargai praktek agama Islam yang ada di Desa Jayamekar seperti misalnya adanya pengajian yang menggunakan pengeras suara, masyarakat non-Islam tidak berkeberatan.

\subsubsection{Asimilasi}

Salah satu contoh asimilasi yang terjadi di Desa Jayamekar adalah pernikahan antara masyarakat desa dengan masyarakat pendatang atau masyarakat dari luar Desa Jayamekar, pernikahan tersebut tidak hanya menyatukan dua individu semata tetapi membawa dua keluarga yang berbeda untuk menerima dan menghargai budaya masing-masing, pada akhirnya muncul perpaduan antara budaya yang berasal dari Desa Jayamekar dengan budaya yang berasal dari luar Desa Jayamekar.

\subsubsection{Bentuk Interaksi Sosial Disasosiatif di Desa Jayamekar}

\section{A. Persaingan}

Bagaimanapun interaksi yang terjalin antara masyarakat desa dengan masyarakat pendatang apabila dihadapkan kepada kebutuhan atau tuntutan yang sama maka akan menimbulkan persaingan. Persaingan yang terjadi lebih kepada persaingan ekonomi, bukan kepada persaingan nilai atau budaya. Persaingan ekonomi yang terjadi di Desa Jayamekar tidak terjadi di sektor formal seperti di instansi pemerintah atau perusahaan swasta, tetapi persaingan terjadi di sektor non-formal, hal ini salah satunya diakibatkan oleh makin sedikitnya lahan pertanian yang dialihfungsikan kepada pembangunan perumahan sehingga berkurangnya sumber mata pencaharian, masyarakat desa yang dahulunya mencari nafkah di bidang pertanian, kini harus mencari mata pencaharian lainnya dan bersaing dengan masyarakat pendatang, seperti contohnya persaingan dalam membuka toko, warung, kios, atau usaha dagang lainnya. Namun persaingan tersebut dianggap wajar dan tidak menimbulkan perselisihan atau konflik yang dapat merugikan baik untuk masyarakat desa maupun untuk masyarakat pendatang.

\section{B. Pertentangan/Konflik}

Selama ini belum ditemukan konflik yang terjadi antara masyarakat desa dengan masyarakat pendatang baik itu konflik yang bersifat antar individu, konflik antar individu dengan kelompok maupun konflik antar kelompok. Masyarakat desa memiliki sikap menerima perbedaan sepanjang perbedaan tersebut tidak bertentangan dengan norma-norma agama atau bertentangan dengan peraturan perundang-undangan. Masyarakat desa berpandangan bahwa hidup rukun bersama merupakan suatu kebutuhan, sedangkan perbedaan pendapat merupakan hal yang wajar sepanjang bisa diselesaikan dengan cara melakukan komunikasi yang intensif.

\subsection{Perubahan Sosial Dari Adanya Pembangunan Kompleks Perumahan Di Desa Jayamekar 3.4.1. Perubahan Secara Positif}

Datangnya masyarakat pendatang yang menghuni kompleks perumahan memberikan dampak positif terhadap perubahan sosial masyarakat di Desa Jayamekar, perubahan positif tersebut dapat dikelompokan ke dalam 2 (dua) bentuk perubahan, yaitu perubahan pola pikir dan perubahan pola tindak, berikut adalah penjelasannya:

\section{A. Perubahan Pola Pikir}

Pola pikir masyarakat desa sebelum adanya masyarakat pendatang yang menghuni kompleks perumahan lebih bersifat tertutup, hal ini dikarenakan 2 (dua) faktor, yaitu: Pertama, faktor individu dimana masyarakat desa memiliki tingkat pendidikan rendah, nilai-nilai individu dan nilai-nilai sosial masih 
sangat terbatas dimana masyarakat desa hanya mengenai nilai-nilai internal dari anggota kerabat. Kedua, faktor eksternal yang disebabkan lingkungan sosial dan budaya yang ada di Desa Jayamekar bersifat paternalistik yang mana masyarakat berpandangan tabu dan tidak terbiasa untuk mengungkapkan masalah-masalah yang ada kepada orang lain atau kelompok masyarakat diluar garis keturunannya. Kedua faktor tersebut didukung dengan pola hunian yang bersifat mengelompok untuk satu keluarga tertentu, artinya anggota keluarga dari satu garis keturunan akan cenderung memiliki rumah di kawasan yang sama atau berdekatan.

Pembangunan kompleks perumahan yang dilakukan di Desa Jayamekar merubah tatanan sosial tersebut, selain adanya perubahan pola ruang pembangunan perumahan yang mengakomodir masyarakat pendatang untuk menetap dan bertempat tinggal di desa tersebut, masyarakat dituntut untuk mampu bersikap terbuka dan menerima masyarakat pendatang dengan nilai-nilai sosial yang dibawanya. Implikasinya masyarakat desa semenjak datangnya masyarakat pendatang lebih bersifat terbuka dan menerima ide-ide/nilai-nilai sosial baru yang dibawa masyarakat pendatang untuk kemudian disesuaikan dengan nilai-nilai yang ada.

Pola pikir tersebut dapat dilihat dari yang dahulunya masyarakat desa menaruh rasa curiga dan prasangka terhadap masyarakat dari luar, saat ini masyarakat desa mulai berfikir rasional dimana setiap adanya masyarakat pendatang dengan membawa nilai-nilai baru, masyarakat desa akan mempertimbangkan manfaat baik dan buruknya untuk kemudian diambil sikap lebih lanjut. Hal lain juga ditunjukan dengan cara pola fikir masyarakat desa yang akan menyaring terlebih dahulu berbagai isu yang ada untuk mencari kebenarannya, ditambah pola pikir yang dahulunya bersifat irasional atau menanggapi

suatu fenomena dengan pedekatan mistik lambat laun digantikan dengan pola fikir logis-rasional.

Pola pikir yang lebih terbuka juga ditujukan oleh masyarakat desa yang menerima akan perbedaan keyakinan atau agama yang dibawa masyarakat pendatang, masyarakat desa menerima perbedaan tersebut dan berpandangan bahwa perbedaan tersebut merupakan bagian dari keberagaman. Implikasi dari hal tersebut adalah meningkatnya rasa toleransi masyarakat desa terhadap perbedaan yang ada.

Selain itu, dampak lain dari perubahan pola fikir yang lebih terbuka ditunjukan dengan orientasi masyarakat desa yang menekankan kepada masa kini dan masa depan, seperti pandangan masyarakat desa yang dahulunya menganggap bahwa mencari nafkah/mata pencaharian jauh lebih penting dibanding dengan melanjutkan pendidikan ke jenjang lebih tinggi digantikan dengan pola pikir masyarakat desa yang menganggap bahwa pendidikan sampai dengan jenjang perguruan tinggi adalah penting dan dapat memperbaiki kehidupan.

\section{B. Perubahan Pola Sikap}

Perubahan pola sikap masyarakat desa tidak bisa dilepaskan dari perubahan pola pikir yang ada di masyarakat, implikasi dari perubahan sikap masyarakat desa dijelaskan sebagai berikut:

\section{- Sikap Terbuka}

Sikap pertama yang ditunjukan oleh masyarakat desa dengan adanya masyarakat pendatang yang menghuni kompleks perumahan yang dibangun di Desa Jayamekar adalah sikap terbuka menerima keberadaan masyarakat pendatang tersebut. Penerimaan tersebut disebabkan oleh dua faktor utama: Pertama, faktor yang berasal dari masyarakat pendatang dimana masyarakat pendatang menghormati nilai-nilai yang ada dan dipraktekan di Desa Jayamekar, hal lain yang ditunjukan oleh masyarakat pendatang adalah menyesuaikan kebiasaan dan perilakunya dengan masyarakat desa sepanjang tidak bertentangan dengan nilai-nilai prinsipal dan keyakinan. Kedua, faktor yang berasal dari masyarakat desa itu sendiri, dengan melihat sikap dan perilaku masyarakat pendatang yang mau menerima nilai-nilai yang ada di Desa Jayamekar dan mau menyesuaikan diri menimbulkan kesan dan sikap positif bagi masyarakat desa untuk menerima dan terbuka kepada keberadaan masyarakat pendatang dikarenakan sikap dan perilaku yang ditunjukan tersebut tidak bertentangan dengan sikap dan perilaku masyarakat desa yang ada selama ini. 


\section{- Sikap Toleransi}

Sikap lebih lanjut dari adanya sikap terbuka masyarakat desa kepada keberadaan masyarakat pendatang yaitu timbulnya sikap toleransi terhadap perbedaan yang ada. Masyarakat desa menyadari bahwa tidak semua perbedaan dapat diselesaikan dengan cara adaptasi dan penyesuaian, hal-hal yang berhubungan dengan sikap dan perilaku dalam interaksi sosial antara masyarakat desa dengan masyarakat pendatang masih bisa disikapi dengan cara saling menyesuaikan satu dengan yang lain. Namun dalam halhal yang bersifat prinsipal perbedaan tersebut hanya bisa diselesaikan dengan sikap toleransi, hal ini bisa dilihat dari adanya masyarakat pendatang yang memiliki agama yang berbeda (diluar Agama Islam) seperti dapat dilihat dari tabel 8 berikut ini:

Tabel 8. Agama/Keyakinan Masyarakat. (BPS Kabupaten Bandung Barat, 2018)

\begin{tabular}{|lcccc|}
\hline Agama/Kepercayaan & Katolik & Protestan & Hindu & Budha \\
\hline Jumlah/jiwa & 270 & 488 & - & - \\
\hline
\end{tabular}

Masyarakat desa harus menerima dan bersikap terbuka terhadap perbedaan agama yang ada. Berdasarkan hasil penelitian menunjukan adanya sikap toleransi yang ditunjukan baik oleh masyarakat desa maupun oleh masyarakat pendatang, kedua masyarakat tersebut menghargai praktek-praktek penyelenggaraan peribadahan dari masing-masing agama yang dianut oleh masyarakat dengan cara tidak mengganggu warga masyarakat yang sedang beribadah. Bahkan sebagian masyarakat membatu warga lainnya untuk memperlancar jalannya ibadah atau kegiatan agama seperti membantu kelancaran jalan/lalu lintas dalam acara pengajian yang dilakukan oleh salah satu anggota masyarakat yang kebetulan menggunakan sebagian ruas jalan, serta bentuk toleransi lainnya.

Sikap toleransi juga ditunjukan tidak hanya dalam masalah perbedaan agama semata, tetapi juga ditunjukan dalah bentuk lainnya seperti penyelenggaraan pesta pernikahan dimana adanya warga masyarakat yang menyelenggarakan pesta pernikahan dengan menggunakan budaya/tradisi lain (diluar budaya Sunda) yang mana warga tersebut berasal dari daerah tersebut, masyarakat desa menerima dan menghadiri pesta pernikahan tersebut dan menganggap bahwa perbedaan itu wajar dan harus diterima oleh semua pihak. Sikap toleransi ini pada akhirnya berakibat positif kepada kehidupan masyarakat desa yang mana masyarakat hidup berdampingan secara rukun dan tidak adanya konflik yang muncul dari adanya perbedaan-perbedaan tersebut.

\section{- Sikap Bekerjasama}

Sikap bekerjasama merupakan sikap yang ditunjukan sebagai adanya keterbukaan dan toleransi yang ditunjukan baik oleh masyarakat desa maupun dari masyarakat pendatang. Seperti yang sudah dijelaskan sebelumnya, kerjasama yang dilakukan oleh kedua masyarakat dilakukan dalam berbagai bidang baik bidang pembangunan desa maupun bidang ekonomi seperti jasa dan perdagangan. Hubungan kerjasama tersebut pada akhirnya memberi dampak positif kepada kedua belah pihak dan secara langsung mendorong perubahan sosial yang ada di Desa Jayamekar.

Dari pemahaman di atas, maka perubahan nilai-nilai yang ada di Desa Jayamekar atau disebut dengan nilai-nilai lama dan nilai-nilai baru yang terbentuk setelah adanya interaksi masyarakat desa dengan masyarakat pendatang antara lain dapat dijelaskan dalam tabel 9 berikut ini:

Tabel 9. Nilai-Nilai Masyarakat Lama dan Nilai-Nilai Masyarakat Baru (Analisis Peneliti, 2018)

\begin{tabular}{lll} 
- Nilai-Nilai Lama Masyarakat Desa & Nilai-Nilai Baru Pasca Adanya Masyarakat Pendatang \\
- Bersikap ekslusif. & $\bullet$ Bersikap Inklusif. \\
- Rraduga terhadap pendatang. & $\bullet$ Terbuka terhadap pendatang. \\
- Kesamaan keturunan sebagai dasar interaksi. & - Kesamaan kepentingan sebagai dasar interaksi. \\
\hline
\end{tabular}


Dari tabel di atas didapat informasi bahwa pada awalnya masyarakat desa memiliki sifat tertutup terhadap masyarakat luar, interaksi yang terjalin bersifat ekslusif diantara anggota masyarakat yang memiliki ikatan kekeluargaan atau bertempat tinggal di lingkungan yang sama/tetangga. Namun datangnya masyarakat pendatang yang menghuni kompleks perumahan mengakibatkan masyarakat desa harus membuka diri dan melakukan interaksi dengan masyarakat pendatang tersebut, hal ini dikarenakan baik masyarakat desa maupun masyarakat pendatang memiliki kepentingan yang harus melibatkan interaksi diantara keduanya, lambat laun dengan adanya sikap menerima dan melakukan interaksi maka masyarakat desa menjadi terbuka dan menganggap bahwa keberadaan masyarakat pendatang menjadi bagian dari kehidupan masyarakat desa saat ini.

\subsubsection{Perubahan Secara Negatif}

Perubahan sosial yang terjadi di Desa Jayamekar tidak hanya berlangsung secara positif ke arah yang lebih baik, tetapi juga berlangsung secara negatif yang mana perubahan tersebut justru memunculkan kerugian baik bagi masyarakat desa maupun bagi masyarakat pendatang, berikut adalah penjelasannya:

\section{A. Munculnya Sikap Individualistis}

Sebagian masyarakat pendatang yang menghuni kompleks perumahan memiliki sikap individualistis, dimana mereka memiliki orientasi kepada kepentingan dirinya sendiri, interaksi sosial yang dijalin dengan masyarakat desa bersifat terbatas, artinya masyarakat pendatang tersebut akan berinteraksi dengan masyarakat desa sepanjang dirinya memiliki kepentingan atau akan mendapatkan manfaat dari proses interaksi tersebut. Sikap individualis yang mana memusatkan perhatian kepada kepentingan pribadi tentu saja bertentangan dengan nilai-nilai sosial yang sudah ada di Desa Jayamekar dimana nilai kekeluargaan, kebersamaan dan gotong-royong menjadi landasan dalam interaksi sosial antara sesama warga masyarakat.

Meskipun sikap individualistis tersebut bertentangan dengan nilai-nilai yang ada di Desa Jayamekar, akan tetapi fenomena yang ada menunjukan bahwa sikap individualistis diadopsi oleh sebagian masyarakat desa baik secara sadar maupun secara tidak sadar, terdapat beberapa anggota masyarakat yang menunjukan sikap individualistis. Hal ini bisa dilihat dalam kegiatan pembangunan desa, anggota masyarakat yang memiliki sikap individualistis cenderung tidak terlibat dan tidak ikut memberikan kontribusinya dalam proses perencanaan pembangunan desa yang sedang dilaksanakan karena beranggapan tidak akan memberikan dampak atau manfaat kepada dirinya. Munculnya sikap individualistis tersebut pada akhirnya merubah pola interaksi sosial yang ada di Desa Jayamekar ke arah negatif. Sikap individualistis tersebut memberi dampak yang buruk khususnya kepada sikap kepedulian sosial dan gotong royong yang selama ini ada di Desa Jayamekar.

\section{B. Menurunnya Sikap Kepedulian Sosial}

Rasa kepedulian sosial yang ada di Desa Jayamekar menunjukan gejala penurunan, salah satu penyebabnya adalah menurunya intensitas interaksi sosial yang didasarkan kepada sikap peduli dan tanpa pamrih. Dahulunya interaksi sosial yang ada di Desa Jayamekar terjalin secara intens dalam berbagai bentuk kegiatan tanpa terikat konteks ruang dan waktu, seperti contohnya ketika ada anggota masyarakat dari keluarga kurang mampu menderita sakit, maka anggota masyarakat lainnya akan secara suka rela mengumupulkan uang untuk membantu, apabila warga masyarakat tersebut diharuskan dirawat di rumah sakit, maka masyarakat dengan sigap mengantarkan ke rumah sakit, bahkan sebagian dari mereka menunggu di rumah sakit secara bergiliran sampai anggota masyarakat yang sakit tersebut sembuh. Apa yang dilakukan masyarakat tersebut didasarkan kepada sikap tanpa menginginkan imbalan.

Namun kondisi saat ini menunjukan jarang ada lagi sikap kepedulian sosial dengan cara mengumpulkan uang untuk membantu warga masyarakat yang menderita sakit. Sikap masyarakat apabila mengetahui ada warganya dari keluarga miskin yang menderita sakit, maka akan langsung meminta Kepala Desa atau aparatur desa untuk mengurusi tanggungan asuransi BPJS (Badan Penyelenggara Jaminan Kesehatan), masyarakat menganggap dengan melaporkan kepada Kepala Desa atau aparatur desa maka 
permasalahan tersebut akan dapat diatasi. Sikap yang ditujukan masyarakat saat ini menunjukan telah terjadi penurunan rasa kepedulian sosial dan mengalami perbedaan apabila dibandingkan dengan waktu terdahulu, meskipun secara individu atau perorangan anggota masyarakat yang memiliki ikatan keluarga atau tetangga masih menunjukan sikap kepedulian sosial dengan menjenguk secara pribadi.

Hal lain juga bisa dilihat apabila ada anggota masyarakat yang mengadakan pesta pernikahan, anggota masyarakat lainnya akan secara otomatis bantu-membantu dalam menyukseskan penyelanggaraan pernikahan tersebut. Kaum pria akan bersama-sama membangun tenda dan mempersiapkan sarana yang dibutuhkan, sementara kaum perempuan akan bersama-sama membuat dan menghidangkan makanan untuk resepsi pernikahan. Keterlibatan masyarakat desa tersebut didasarkan atas adanya rasa kebersamaan dan kepedulian sosial, sehingga masyarakat desa yang terlibat di dalamnya tidak mengharapkan imbalan. Namun dalam konteks saat ini, keterlibatan masyarakat desa dalam pesta pernikahan banyak didasarkan kepada imbalan. Hanya sedikit masyarakat yang masih rela untuk meluangkan waktu membantu warga masyarakatnya yang akan melangsungkan pesta pernikahan tanpa mengharapkan imbalan. Sebagian masyarakat yang ada saat ini mengharapkan imbalan baik dalam bentuk uang maupun dalam bentuk lainnya.

Sikap masyarakat desa seperti yang telah dijelaskan di atas menurut hasil penelitian yang dilakukan salah satu faktor penyebabnya dikarenakan mengikuti gaya atau kebiasaan masyarakat pendatang yang menghuni kompleks perumahan di Desa Jayamekar. Masyarakat pendatang apabila akan mengadakan pesta pernikahan atau acara lainnya akan melibatkan masyarakat sekitar dan memberikan upah atau imbalan dari keterlibatan masyarakat tersebut. Kebiasaan inilah yang diadopsi oleh masyarakat desa dan mengakibatkan masyarakat memiliki sikap pamrih, sehingga menurunkan rasa kepedulian sosial.

\section{Munculnya Sikap Oportunis}

Dampak negatif lainnya yaitu adanya sikap oportunis anggota masyarakat desa, hal ini salah satunya disebabkan oleh karakter sebagian masyarakat pendatang yang menghuni kompleks perumahan yang apabila melakukan interaksi dengan masyarakat desa didasarkan karena adanya kepentingan. Sehingga apabila masyarakat pendatang tersebut membutuhkan bantuan masyarakat desa, maka sikap masyarakat desa tidak lagi membantu dengan tanpa mengharapkan imbalan, tetapi akan membantu apabila ada imbalan yang sesuai dengan hasil kerja mereka. Terlebih lagi apabila kegiatan tersebut murni dilakukan untuk kepentingan masyarakat pendatang seperti acara pesta pernikahan ataupun acara pesta khitanan, keterlibatan masyarakat desa dalam kegiatan tersebut didasarkan kepada imbalan dari keterlibatan masyarakat desa. Implikasi dari permasalahan tersebut yaitu masyarakat desa akan terlibat sepanjang ada imbalan dari keterlibatan tersebut, apabila tidak ada imbal jasa maka hanya akan ada sedikit masyarakat desa yang terlibat.

Penyebab lainnya mengapa masyarakat bersifat oportunis dikarenakan sudah banyaknya pekerjaan yang diambil alih oleh masyarakat pendatang, sehingga kesempatan mencari pekerjaan bagi masyarakat desa menjadi berkurang. Apabila ada acara atau kegiatan yang dilaksanakan, maka sebagian masyarakat desa menganggapnya sebagai peluang untuk mendapat pekerjaan/penghasilan meskipun secara serabutan atau aksidental.

\subsection{Prakiraan Dampak Lanjutan Perubahan Sosial}

Perubahan sosial yang ada di Desa Jayamekar tidak akan berhenti pada saat ini saja, melainkan akan terus berlanjut sebagai konsekuensi akan terus datangnya masyarakat pendatang yang menghuni kompleks perumahan yang telah dibangun atau sedang dibangun, juga dikarenakan perkembangan lainnya baik di internal maupun di eksternal Desa Jayamekar, prakiraan lanjutan dari perubahan sosial yang mungkin akan terjadi sebagaimana dapat dijelaskan dalam tabel 10 berikut ini:

Tabel 10. Prakiraan Perubahan Sosial Lanjutan (Analisis Peneliti, 2018)

\begin{tabular}{ll}
\multicolumn{1}{c}{ Aspek } & Prakiraan Perubahan Sosial Lanjutan \\
Pola Pikir & Pola pikir masyarakat desa akan semakin terbuka dan kritis, masyarakat desa tidak hanya \\
\hline
\end{tabular}




\begin{tabular}{|ll|}
\hline & bersifat terbuka kepada masyarakat pendatang, tetapi juga akan bersikap kritis terhadap nilai- \\
& nilai sosial yang dibawa, masyarakat desa akan membandingkan dan menganalisis dari nilai- \\
& nilai sosial tersebut dan tidak menuntut kemungkinan apabila nilai-nilai sosial tersebut \\
& bertentangan dengan apa yang ada, maka akan terjadi benturan yang bersifat \\
& persaingan/kompetisi yang memungkinkan adanya konflik nilai/budaya. \\
\hline Pola Tindak & Sikap masyarakat tidak hanya akan dipengaruhi oleh sikap atau keinginan menciptakan \\
& lingkungan yang harmonis di Desa Jayamekar, tetapi juga akan dipengaruhi aspek lainna, \\
& salah satu aspeknya yaitu adanya kepentingan individu, akan muncul persaingan untuk \\
& mendapatkan pekerjaan dan kedudukan sosial di masyarakat, hal ini akan berakibat tindakan \\
& yang dilakukan akan berorientasi kepada kepentingan individu, bukan lagi kepada \\
& kepentingan bersama/sosial, masyarakat akan lebih bertindak praktis dan rasional serta \\
& berorientasi kepada manfaat atau keuntungan dari tindakan yang akan diambil/dikerjakan \\
& tersebut, sehingga akan semakin menurunkan sikap solidaritas sosial dan meningkatkan sikap \\
& individualistis. \\
\hline Pola & Penduduk yang ada di Desa Jayamekar akan semakin bertambah baik dikarenakan \\
Sosial & pertumbuhan penduduk masyarakat desa maupun dari kedatangan masyarakat luar desa yang \\
& akan menghuni kompleks perumahan yang telah dan sedang dibangun, konsekuensinya \\
& interaksi sosial akan semakin intens dalam berbagai aspek kehidupan. Tingginya tingkat \\
& interaksi sosial tersebut apabila tidak diimbangi dengan keuntungan bersama maka akan \\
& memunculkan konflik kepentingan dan konflik sosial dimana masyarakat desa akan bersaing \\
& secara langsung dengan masyarakat pendatang dalam banyak hal dimana masyarakat yang \\
& satuakan mendominsasi masyarakat lainnya. \\
\hline
\end{tabular}

\section{KESIMPULAN}

Pembangunan perumahan telah mendorong masyarakat pendatang untuk tinggal di kompleks perumahan yang ada di Desa Jayamekar, konsekuensinya yaitu memberikan perubahan terhadap kehidupan masyarakat desa. Dalam hal perubahan sosial yang ada di Desa Jayamekar dapat dikategorikan kepada perubahan sosial secara positif dan perubahan sosial secara negatif yang mencakup perubahan pemikiran dan perubahan sikap. Perubahan sosial secara positif bisa terlihat seperti: masyarakat desa mengadopsi nilai-nilai budaya yang berasal dari luar seperti berfikir logis dan rasional, memiliki orientasi terhadap pencapaian kehidupan di masa kini dan untuk masa depan, masyarakat desa bersikap lebih terbuka terhadap kedatangan masyarakat pendatang dan menumbuhkan rasa toleransi terhadap segala perbedaan yang ada, sedangkan dampak negatif bisa terlihat dari menurunnya rasa solidaritas sosial dan meningkatnya rasa individualistis masyarakat desa. Meskipun demikian, secara keseluruhan perubahan sosial tersebut telah membentuk suatu nilai-nilai baru sebagai implikasi dari adanya akulturasi nilai lokal Desa Jayamekar dengan nilai dari luar yang dibawa oleh masyarakat pendatang. Nilai-nilai baru tersebut pada akhirnya dijadikan pedoman dan landasan dalam tataran sosial interaksi antara masyarakat desa dengan masyarakat pendatang yang ada di Desa Jayamekar.

Adanya perubahan sosial masyarakat desa tersebut perlu diantisipasi lebih lanjut dengan cara pembuatan instrumen kebijakan agar perubahan sosial yang terjadi dapat terus membawa dampak positif, adapun rekomendasi untuk permasalahan tersebut yaitu: 1) Perubahan sosial akan terus berlangsung sebagai dampak dari adanya pembangunan kompleks perumahan, oleh sebab itu perlindungan dan pemberdayaan masyarakat desa mutlak diperlukan sebagai ciri dari pembangunan yang mengakomodir sumber daya local; 2) Perubahan sosial harus mampu bersinergi dengan perubahan lainnya seperti perubahan infrastruktur, perubahan ekonomi dan perubahan budaya, hal ini menjadi penanda bahwa perubahan berlangsung secara kompleks dan multi aspek yang harus berjalan secara terpadu; 3) Akulturasi nilai-nilai lokal yang ada di Desa Jayamekar dengan nilai-nilai luar yang dibawa masyarakat pendatang penghuni kompleks perumahan mutlak harus dilakukan secara kontinyu sebagai bentuk penyesuaian terhadap eksistensi nilai masing-masing yang ditunjukan untuk mempertahankan nilai-nilai yang ada dan menciptakan suatu tatanan nilai-nilai baru yang harmonis. 


\section{REFERENSI}

Abrams, C. (1964). Man's Struggle for Shelter in An Urbanizing World. Cambridge: M.I.T. Press.

Alo, L. (1991). Komunikasi Antar Pribadi. Bandung: PT Citra Aditya Bakti.

Batudoka, Z. (2005). Kota Baru Dan Aspek Permukiman Mendepan. Jurnal SMARTek, 3(1), 27-36.

BPS Kabupaten Bandung Barat. (2018). Kecamatan Padalarang Dalam Angka Tahun 2018. Kabupaten Bandung Barat.

Creswell, J. W. (2007). Qualitative Inquiry and Reseach Design: Choosing Among Five Approaches (3rd Editio). Thousand Oaks: Sage Publications.

DeVault, M. L., Denzin, N., \& Lincoln, Y. (1995). Handbook of Qualitative Research. Thousand Oaks: Sage.

Dewi, I. A. L., \& Sarjana, I. M. (2015). Faktor-Faktor Pendorong Alihfungsi Lahan Sawah Menjadi Lahan NonPertanian (Kasus : Subak Kerdung, Kecamatan Denpasar Selatan). Manajemen Agribisnis, 3(2), 163-171.

Diningrat, R. A. (2014). Ketergantungan Kota Baru Kota Harapan Indah terhadap Kota Jakarta dan Wilayah Sekitarnya. Jurnal Perencanaan Wilayah Dan Kota, 25(3), 192-212.

Epstein, B. J. (1969). External Relations Of Cities: City-Hinterland. Journal of Geography.

Fiske, J. (2011). Cultural and Communication Studies. Yogyakarta: Jalansutra.

Giyarsih, S. R. (2001). Gejala Urban Sprawl sebagai Pemicu Proses Densifikasi Permukiman di Daerah Pinggiran Kota (Urban Fringe Area). Jurnal Pembangunan Wilayah, 12(1), 40-45.

Harjanto, B., \& Hidayati, W. (2003). Konsep Dasar Penilaian Properti (BPFE). Yogyakarta.

Harmono. (2015). Memotret Konflik Elit Politik Di pedesaan. Jurnal Logika, 14(2), 81-87.

Husodo, H. S. (2018). Wajah Padalarang Sebagai Pusat Bisnis Akan Tampak Pada 2018. Retrieved from http://www.pikiran-rakyat.com/ekonomi/2016/02/01/359341/wajah-padalarang-sebagai-pusat-bisnisakan-tampak-pada-2018

Kalsum, E., Caesariadi, \& Wibowo, T. (2016). Konsep Permukiman Kota Terpadu Mandiri. Jurnal Langkau Betang, 3(2), 12-24.

Luthfia, A. R. (2013). Menilik Urgensi Desa Di Era Otonomi Daerah. Journal of Rural and Development, 3(2), $136-137$.

Masruri, S., \& Lukman, F. R. (2013). Peran Modal Sosial filsafat Tri Tangtu Silih Dalam Pemberdayaan Ekonomi Masyarakat Di Desa Alamendah Rancabali Bandung. Jurnal INFERENSI, 7(2), 277-281.

Moleong, L. J. (2017). Metodologi Penelitian Kualitatif (Edisi Revisi). Yogyakarta: PT. Remaja Rosda Karya.

Nawawi, H. (2007). Metode Penelitian Bidang Sosial. Yogyakarta: Gajah Mada Press.

Pemerintah Desa Jayamekar. (2018). Profil Desa Jayamekar Tahun 2018. Kabupaten Bandung Barat.

Potabuga, J. (2015). Peran Kepala Desa Dalam Pelayanan Publik (Studi di Desa Pontak Kabupaten Minahasa Selatan). Jurnal Acta Diurna, 4(2).

Purnomo, D. (2009). Fenomena Migrasi Tenaga Kerja Dan Perannya Bagi Pembangunan Daerah Asal: Studi Empiris Di Kabupaten Wonogiri. Jurnal Ekonomi Pembangunan, 10(1), 84-102.

Ritonga, A. S., \& Bahri, S. (2017). Asimilasi Budaya Melayu Terhadap Budaya Pendatang Di Kecamatan Senapelan Kota Pekanbaru, 4(2), i-xiii.

Rusdiyanta, \& Syarbaini, S. (2009). Dasar-Dasar Sosiologi. Yogyakarta: Graha Ilmu.

Sari, M. S., Safitri, D., \& Sugito. (2014). Klasifikasi Wilayah Desa-Perdesaan Dan Desa-Perkotaan Wilayah Kabupaten Semarang Dengan Support Vector Machine (SVM). Jurnal Gaussian, 3(4), 751-760.

Soekanto, S. (1994). Pengantar Sosiologi. Jakarta: Raja Grafindo.

Sugiyono. (2013). Metode Penelitian Pendidikan Pendekatan Kuantitaif, Kualitatif, dan R\&D. Bandung: Alfabeta.

Suparman, A. (2016). Desa dan Hak-Hak Tradisional. Jurnal Wawasan Hukum, 26(1), 464-470.

Vioya, A. (2010). Tahapan Perkembangan Kawasan Metropolitan. Jurnal Perencanaan Wilayah Dan Kota, 21(3), 215-226.

Walgito, B. (2010). Pengantar Psikologi Umum. Yogyakarta: Andi Ofset. 